\title{
PELESTARIAN KEARIFAN LOKAL \\ MELALUI PERKAWINAN ENDOGAMI \\ DI DESA TENGANAN PEGRINGSINGAN KARANGASEM \\ DALAM PERSPEKTIF INTERAKSI SIMBOLIK
}

\author{
Putri Ekaresty Haes \\ Universitas Pendidikan Nasional \\ ekarestyhaes@undiknas.ac.id
}

\begin{abstract}
ABSTRAK
Kebudayaan memiliki kegunaan yang besar bagi kehidupan manusia, karena manusia merupakan makhluk yang berbudaya, dan melalui akal budinya manusia dapat mengembangkan kebudayaan, sehingga selama manusia hidup akan sangat mempengaruhi sebuah kebudayaan sebagai sebuah ciptaan manusia. Manisfesitasi tersebut meliputi agama, kesenian, filsafat, ilmu pengetahuan, tata negara, sistem perkawinan dan lain sebagainya. masyarakat Desa Tenganan Pengringsingan mengenal sistem perkawinan endogami desa yaitu perkawinan antar anggota desa, sistem perkawinan ini dipakai karena akan menambah jumlah krama desa suci (karma desa asli). Sistem perkawinan endogami yang dilakukan oleh masyarakat desa Tenganan merupakan sebuah upaya pelestarian nilainilai kearifan lokal desa setempat. Selain itu, Sistem perkawinan ini bertujuan agar kepemilikan lahan serta rumah yang ada di desa Tenganan menjadi milik masyarakat desa setempat dan dimiliki oleh masyarakat luar. Pelestarian nilai-nilai kearifan lokal yang terjadi di desa Tenganan khususnya sistem perkawinan endogami terbentuk melalui proses komunikasi yang telah terbangun lama. Dalam proses komunikasi tersebut, individu dalam masyarakat melakukan interaksi dan memberikan makna terhadap simbol-simbol yang ada. Dalam sistem adat perkawinan Endogami di desa Tenganan Pengringsingan terdapat banyak simbol-simbol yang dipergunakan dalam pelaksanaan upacara perkawinan tersebut yang oleh Blumer dalam perspektif interaksi simbolik dalam diklasifikasikan keadalan ketiga premis yang diungkapkan oleh Blumer.
\end{abstract}

Kata Kunci : Kebudayaan, Sistem Perkawinan Endogami, Interaksi Simbolik, Desa Tenganan Pegringsingan 


\begin{abstract}
Culture has great uses for human life, because humans are cultured creatures, and through their intellect, humans can develop culture, so that as long as humans live, it will greatly affect a culture as a human creation. The manifestations of culture in human sociality includes religion, art, philosophy, science, state administration, marriage system and others. Tenganan Pengringsingan villagers are familiar with the endogamy marriage system which is the marriage that conducted with the local residents of the same village. These kind of marriage system will increase the number of sacred village manners (original village karma). The endogamy marriage system carried out by the Tenganan village community is an effort to preserve the local wisdom of the local village. In addition, this marriage system aims to make ownership of land and houses in the village of Tenganan belong to the local village community and owned by outside communities. Preservation of the values of local wisdom that occur in the village of Tenganan, especially the endogamy marriage system is formed through a longestablished communication process. In the communication process, individuals in the community interact and give meaning to the symbols that exist. In the Endogamy traditional marriage system in the village of Tenganan Pengringsingan there are many symbols used in the implementation of the marriage ceremony which in the perspective of symbolic interaction in classified the third premise expressed by Blumer.
\end{abstract}

Keywords: Culture, Endogamy Marriage System, Symbolic Interaction, Tenganan Pegringsingan Village

\title{
PENDAHULUAN
}

Kebudayaan memiliki kegunaan yang besar bagi kehidupan manusia, karena manusia merupakan makhluk yang berbudaya, dan melalui akal budinya manusia dapat mengembangkan kebudayaan, sehingga selama manusia hidup akan sangat mempengaruhi sebuah kebudayaan sebagai sebuah ciptaan manusia. Herusatono (2012) menyatakan bahwa kebudayaan merupakan manifestasi dari kehidupan manusia yang berbudi luhur dan yang bersifat rohani. Manisfesitasi tersebut meliputi agama, kesenian, filsafat, ilmu pengetahuan, tata negara dan lain sebagainya. Dari pendapat tersebut maka terdapat hubungan dialektika antara kebudayaan dengan manusia yaitu kebudayaan adalah produk manusia, namun manusia itu sendiri merupakan produk kebudayaan, dengan kata lain kebudayaan itu ada karena manusia dan sebagai penciptanya dan manusia hidup ditengah kebudayaan ciptaannya, sehingga kebudayaan akan terus hidup manakala manusia sebagai pendukungnya tetap ada.

Indonesia sebagai sebuah negara kepulauan memiliki beraneka ragam adat, nilai, budaya. Agama maupun kebiasaan hidup. Heterogenitas struktur kehidupan masyarakat semacam ini dipandang sebagai potensi kekayaan bangsa dan warisan budata yang perlu dipahami oleh setiap lapisan masyarakat. Salah satu dari warisan tersebut adalah sistem 
kekerabatan yang sampai sekarang masih ada pada masyarakat Indonesia. Dalam sistem kekerabatan di Indonesia mengenal tiga sistem yaitu parental, patrilinear dan matrilinear. Dalam sistem kekerabatan parental kewajiban sebagai orang tua kepada anak hanya sampai anak tersebut dewasa dan dapat hidup mandiri, dalam sistem parental tanggung jawab ini tidak hanya dibebankan pada bapak saja tetapi juga ibu. Sistem kekerabatan parental ini lebih banyak dianut oleh suku Jawa dan Sunda. Sistem kekerabatan Matrilineal merupakan sistem kekerabatan dimana susunan kekerabatan memprioritaskan pada garis keturunan ibu sebagai penerus, sistem ini dipergunakan pada masyarakat adat suku Minangkabau. Sedangkan sistem patrilineal susunan kekerabatan lebih memprioritaskan garis keturunan laki-laki sebagai penerus. Sistem ini digunakan hampir pada semua suku yang ada di Indonesia salah satunya adalah masyarakat adat di Bali.

Masyarakat Bali hidup secara berkelompok dalam satu desa pakraman (dulu desa adat) sebagai kesatuan masyarakat. Korn (1978) dalam Budiyana (2018:2) pada hakikatnya sistem kekerabatan yang dianut oleh masyarakat Hindu di Bali adalah sistem kekerabatan patrilineal. Keturunan ditarik dari garis keturunan laki-laki (purusa). Dalam hubungan ini bila terjadi perkawinan, seorang wanita kawin akan masuk dalam rumpun keluarga laki-laki (suami) yang selanjutnya meneruskan keturunan dalam keluarga laki-laki. Pihak laki-laki dipandang sebagai pelanjut dan bertanggung jawab terhadap keberlangsungan keluarga baik dalam aspek agama, sosial budaya, hukum, ekonomi dan aspek kehidupan lainnya. Selain sistem kekerabatan patrilineal, dalam masyarakat adat di Bali mengenal sistem pelapisan masyarakat (stratifikasi sosial) yang disebut dengan kasta (wangsa).

Sistem pelapisan sosial kasta pada hakekatnya tidak dikenal di dalam kitab suci Hindu, karena sistem kasta ini akan menempatkan posisi kedudukan masyarakat pada strata yang lebih tinggi atau lebih rendah. Wiana dan Satri dalam Budiyana (2018:3) menyatakan bahwa faktor sosiologis dan historis yaitu pada saat masuknya agama Hindu ke Bali yang dibawa oleh para Maha Rsi dari Jawa Timur menjadi penyebab kasta tumbuh dan berkembang di Bali. Sistem pelapisan sosial kasta tersebut dipengaruhi oleh sistem nilai yaitu utama, madya dan nista. Wangsa yang paling utama adalah golongan Brahmada, kasta madya adalah golongan Kstrya dan kasta nista adalah kaum Waisya. Namun masih ada satu wasta yang dianggap paling rendah yaitu kelompok kaum sudra atau yang sering disebut kaum Jaba Wangsa atau kaum tidak berkasta. Adanya pembagian masyarakat Bali ke dalam atur wangsa ini dalam realitas sosial tidak ada pemilahan atau pemisahan secara ekstrim antara golongan wangsa. Diantara para wangsa tersebut saling berinteraksi dan saling membantu dalam penyelenggaraa upacara- 
upacara keagamaan dalam banjar adat atau desa pakraman. Namun walaupun sistem kasta ini berlaku di pulau Bali, namun tidak semua daerah di Bali menggunakan wangsa tersebut, salah satu Desa di kecamatan Manggis Karangasem yaitu Desa Tenganan.

Desa Tenganan ini memiliki jarak ke pusat pemerintahan kabupaten Karangasem (Kota Amplapura) kurang lebih sekitar 17 kilometer, sedangkan dari pusat kota Denpasar memiliki jarak kurang lebih 65 kilometer. Desa Tenganan merupakan salah satu Desa Kuna (Bali Age) di Bali keberadaannya hingga kini masih mempertahankan tradisi, adat istiadat dan nilai-nilai budaya yang masih berpegang teguh pada aturan adat Desa (awig-awig), karena jika mereka melanggar aturan adat desa akan dikenakan sanksi baik berupa denda maupun dikeluarkan dari keanggotaan krama Desa. Tradisi, adat istiadat, agama, kebudayaan, agama dan kepercayaan masyarakat Desa Tenganan diturunkan oleh para leluhur dan memiliki keunikan tersendiri seperti hukum adat, sistem pola pemukiman, upacara kematian dan juga upacara pernikahan.

Upacara adat perkawinan dapat dipandang sebagai sebuah produk sosial karena secara sosiologis perkawinan mengikat semua unsur dalam kehidupan sosial baik individu maupun masyarakat, upacara adat perkawinan juga merupakan perbuatan magis-religius karena dalam upacara adat perkawinan melibatkan roh-roh leluhur dan agama karena beberapa ritual dalam upacara tersebut wajib dilaksanakan agar prosesi perkawinan serta perjalanan rumah tangga berjalan dengan baik. Untuk itulah maka teori interaksi simbolik karya Blumer dipergunakan sebab Blumer dalam Katamso (2004) mengatakan bahwa interaksi manusia yang terjadi dalam masyarakat dijembatani oleh penggunaan simbol-simbol serta penafsiran dan kepastian makna dari tindakan orang lain bukan hanya sekedar saling berinteraksi sebagaimana model SR (Stimulus-Respon) saja. Adapun tujuan dari penelitian yang telah dilakukan adalah untuk mengetahui pelestarian kearifan budaya lokal melalui perkawinan endogami di Desa Tenganan Pegringsingan Karangasem dalam perspektif Interaksi Simbolik.

\section{KAJIAN TEORI}

\section{Perkawinan Endogami}

Menurut Sunarto (2004) perkawinan endogami merupakan perkawinan dengan anggota dalam kelompok yang sama, sedangkan Goode (2007) menyatakan bahwa perkawinan endogami merupakan suatu bentuk perkawinan yang berlaku dalam masyarakat yang hanya memperbolehkan anggota masyarakat kawin atau menikah dengan anggota lain dari golongan sendiri. Dalam kamus Bahasa Indonesia (2008:372) Perkawinan endogami adalah prinsip 
perkawinan yang mengharuskan orang mencari jodoh dilingkungan sosialnya sendiri. Dari ketiga pengertian tentang perkawinan endogami tersebut maka dapat ditarik pengertian bahwa perkawinan endogami adalah perkawinan yang dilaksanakan pada satu masyarakat yang memperbolehkan anggotanya menikah dengan sesama anggota dalam masyarakat tersebut. Lebih lanjut Sunarto (2004) menyatakan bahwa terdapat bermacam-macam jenis perkawinan endogami yang terjadi dalam masyarakat yaitu : Endogami ras agama, maupun suku. Adapun tujuan dari perkawinan dengan sistem ini adalah untuk menjaga laki-laki sebagai suami tetap diam (bertempat tinggal) di desanya salah satu alasannya agar warisan tetap terjaga dengan baik dan menjaga kemurnian darai dari golongan tertentu.

\section{Teori Interaksi Simbolik Karya Blumer}

Blumer dalam Ritzer (2011:377) mengatakan bahwa sistem sosial, struktur sosial, kebudayaan, posisi status, peran sosial, adat istiadat, institusi, representasi kolektif, situasi sosial, norma sosial, dan nilai merupakan faktor dalam sosial struktural dan sosial kultural. Lebih lanjut Blumer mengatakan bahwa interaksi simbolik tidak hanya tertarik pada sosialisasi saja tetapi juga pada interaksi secara umum yang memiliki arti penting. Blumer dalam Ritz (2011: 377) mengatakan bahwa manusia mengalami proses self indication, yaitu sebuah proses komunikasi di mana individu mengetahui sesuatu, menilainya, memberikan makna, dan memutuskan untuk bertindak berdasarkan makna tersebut. Proses self indication ini terjadi dalam konteks sosial di mana individu mencoba mengantisipasi tindakan-tindakan orang lain dan menyesuaikan tindakannya sebagaimana dia menafsirkan tindakan itu. Lebih lanjut asumsi-asumsi interaksionisme simbolis menurut Blumer dalam Ritzer (2011: 392) bertumpu pada tiga premis yaitu (1) Manusia bertindak terhadap sesuatu atas dasar makna-makna yang dimiliki benda-benda itu bagi mereka, (2) Makna-makna itu merupakan hasil dari interaksi sosial dalam masyarakat manusia satu dengan manusia lainnya, (3) Makna-makna dimodifikasikan dan ditangani melalui suatu proses penafsiran yang digunakan oleh setiap individu dalam keterlibatannya dengan tanda-tanda yang dihadapinya yang disempurnakan di saat proses interaksi sosial berlangsung. Lebih lanjut Irianto (2017:19) interaksi simbolik pada dasarnya menyampaikan pemikiran sebagai berikut: (1) Perhatiannya pad acara manusia merespon kebudayaan melalui membaca situasi dan berinteraksi. Merespon kebudayaan dilakukan demi membangun tentang situasi dan perilaku yang tepat sebagai tanggapan atas situasi tersebut. (2) perhatiannya terhadap relasi antara tindakan, makna (situasi) dan pelaku. 
Dalam beberapa bentuk, hubungan antara aksi, arti dan diri tersebut membangun pengertian tentang identitas dalam kegiatan merespon kebudayaan.

\section{METODE PENELITIAN}

Penelitian kualitatif dengan pendekatan etnografi merupakan salah satu penelitian kualitatif dimana penelitian tersebut mempelajari tentang kelompok sosial ataupun budaya dalam sebuah masyarakat secara lebih mendalam, hal ini lah yang mengharuskan peneliti bersentuhan langsung dan mengikuti keseharian objek yang ditelitinya. Creswell dalam Sugiyono (2014) mengatakan bahwa etnografi merupakan penelitian yang melakukan studi terhadap budaya kelompok dalam kondisi alamiah melalui observasi dan wawancara. Dengan demikian teknik trianggulasi data yang dipergunakan dalam penelitian ini adalah Trianggulasi sumber, waktu, dan teknik sehingga diharapkan mendapatkan hasil yang akurat dari penelitian yang diteliti.

\section{PEMBAHASAN}

Dalam masyarakat Hindu di Bali mengenal siklus kehidupan, terdapat empat fase kehidupan yang disebut sebagai Catur Asrama. Jaman dalam Budiyana (2018: 13) menyatakan bahwa keempat tingkatan perkembangan hidup manusia tersebut terdiri dari: (1) Brahmacari Asrama yaitu kehidupan manusia yang lebih mengedepankan usaha pembelajaran diri. (2) Grihasta asrama, fase kehidupan manusia untuk membentuk rumah tangga, (3) Wanastastha, fase kehidupan manusia yang lebih mengutakan aktivitas spiritual religius, (4) Bhiksuka, tahapan perkembangan manusia untuk mengabdikan secara utuh kepada Hyang Widhi dan berusaha seoptimal mungkin untuk melepskan diri dari ikatan benda duniawi.

Perkawinan atau wiwaha merupakan salah satu cara untuk mewujudkan sirklus hidup Grihasta Asrama. Dalam lontar Agastya-Parwa Sekanda V.14.7 dijelaskan tentang tugas utama dari sirklus hidup Grihasta Asrama yaitu mewujudkan kehidupan yang Grhastha ngarania Sang yatha sakti kayika Dharma yang artinya dengan kemampuan sendiri mengamalkan Dharma. Seorang Grhastha memiliki kemampuan untuk hidup mandiri dan mewujudkan swadharmanya. Dalam masyarakat Bali, perkawinan bukan hanya urusan pribadi yang akan melangsungkan perkawinan tetapi juga menjadi urusan keluarga dan desa adat. Tujuan perkawinan bagi masyarakat hukum adat (desa adat) menurut Hadikusuma dalam Wirata 
(2018: 154) perkawinan secara hukum adat bertujuan untuk mempertahankan dan menerus keturunan menurut garis keturunan, untuk kebahagiaan rumah tangga keluarga / kerabat dan untuk memperoleh nilai-nilai budaya dan kedamaian serta untuk mempertahakan waris. hukum adat perkawinan yang ada di Bali berbeda-beda, hal ini disesuaikan dengan awig-awig (aturan) yang berlaku pada desa adat tersebut. awig-awig (aturan) merupakan tata aturan (baik tertulis maupun tidak tertulis) yang mengatur dan mengendalikan semua aktivitas krama (warga) desa adat.

Kepala desa Tenganan Pegringsingan, Krama desa di daerah Tenganan Pegringsingan mengatakan bahwa desa Tenganan Pegringsingan juga memiliki awig-awig (aturan) sendiri, dan masyarakat di desa ini sangat taat dalam mempertahankan tradisi, adat istiadat, nilai budaya serta agama. Didalam awig-awig (aturan) juga ditetapkan bahwa jika ada warga masyarakat yang melanggar akan di kenakan sanksi adat seperti : tidak diajak mekrama desa serta kehilangan hak serta kewajiban sebagai krama adat, selain itu, konsekwensi lain bagi krama adat yang melanggar adalah dibuang ke banjar Kangin / pande. Sistem perkawinan yang dipergunakan pada desa Tenganan Pegringsingan adalah sistem endogami yaitu pemuda desa Tenganan Pegringsingan harus melakukan perkawinan dengan seorang wanita yang berasal dari desa yang sama. Sesuai dengan yang diungkap oleh Goode (2007) bahwa perkawinan endogami merupakan suatu bentuk perkawinan yang berlaku dalam masyarakat yang hanya memperbolehkan anggota masyarakat kawin atau menikah dengan anggota lain dari golongan sendiri. Sistem perkawinan ini bertujuan agar kepemilikan lahan serta rumah yang ada di desa teta menjadi milik masyarakat desa setempat dan dimiliki oleh masyarakat luar. Dengan melaksanakan pola perkawinan ini secara otomatis pasangan ini akan mendapatkan hak serta melaksanakan kewajiban sesuai dengan awig-awig (aturan) desa yaitu diberikan satu kapling tanah seluas lebih kurang 200 meter persegi serta diperbolehkan menebang pohon-pohon yang ada di hutan untuk membangun rumah. Selain itu, pasangan yang menikah di desa ini juga mendapatan hak atas pemberian beras dari desa yang berasal dari sawah-sawah yang masuk dalam wilayah desa Tenganan serta hak-hak lainnya.

Sebelum melaksanakan adat perkawinan, seorang pemuda desa Tenganan Pegringsingan sesuai dengan awig wajib melaksanakan beberapa ritual yaitu diwajibkan untuk mengikuti kegiatan sekeha teruna serta telah mengikuti upacara meteruna nyoman (upacara akil balik). Dalam upacara meteruna nyoman ini beberapa pemuda akan tinggal didalam 
asrama, mengikuti semua kegiatan yang telah disusun pada malam hari para pemuda ini akan diberikan pembinaan dari keling desa adat dan beberapa tokoh masyarakat. Sedangkan Sedangkan bagi pemudi wajib melaksanakan kegiatan sekeha daha dan mengikuti upacara medaha. Materi yang diberikan bagi pemudi adalah seputar sarana upakara.

Apabila pemuda atau pemudi belum melaksanakan kegiatan ini maka tidak akan diperbolehkan untuk melaksanakan upacara perkawinan dan menjadi krama desa. Dalam awigawig (aturan) desa juga mengatur sanksi yang diberikan apabila ada warga yang melaksanakan perkawinan dengan pemuda atau pemudi diluar desa. Jika seorang pemuda desa Tenganan Pegringsingan melakukan perkawinan dengan wanita dari luar desa atau memiliki istri lebih dari satu maka mereka akan kehilangan hak dan kewajiban mereka sebagai krama adat dan diturunkan statusnya menjadi krama gumipulangan Sedangkan jika seorang pemudi melakukan perkawinan dengan orang luar, maka wanita tersebut akan bertempat tinggal di banjar pande / kangin bersama dengan suami di sebelah Timur desa Tenganan Pegringsingan.

Pola perkawinan endogami yang dilaksanakan di desa Tenganan Pegringsingan yaitu Mepandik / mebase (meminang). Mepandik atau mebase merupakan cara perkawinan yang dilaksanakan seperti perkawinan pada umumnya. Pihak keluarga laki-laki membawa tanda peminangan yang disebut dngan base suhunan berupa base (sirih), buah pinang, mako (tembakau), tebu dan buah-buahan, gula bali kepada pihak keluarga perempan (deha). Tanda peminangan ini dibawa oleh pemuda yang akan meminang dan gadis yang berasal dari keluarga pihak laki-laki. Keluarga pihak laki-laki dan perempuan saling berbicara mengenai maksud dan tujuan dari kedatangan pihak keluarga calon mempelai laki-laki. Setelah pembicaraan selesai, base suhunan diterima oleh pihak keluarga perempuan dan dijadikan sebagai porosan. Porosan ini kemudian diberikan kepada pihak laki-laki sebagai tanda bahwa lamaran dari keluarga pihak laki-laki sudah diterima. sejak diterimanya porosan tersebut maka gadis yang dilamar sudah sah menjadi tunangan (gelan) truna (pemuda) tersebut. Apabila jarak antara pertunangan sampai dengan acara perkawinan jauh maka setiap bulan pihak laki-laki harus membawakan base suluhan kembali menjelang bulan purnama ke keluarga calon mempelai wanita sampai terlaksananya upacara perkawinan.

Setelah hari dan tanggal ditentukan untuk melaksanakan upacara perkawinan, maka keluarga calon mempelai laki-laki datang ke rumah untuk menjemput calon mempelai wanita. Sebelum pergi, kedua calon mempelai mepamit dan bersimbuh di hadapan orang tua calon mempelai perempuan, keluarga calon mempelai perempuan juga ikut mengantar kedua calon 
mempelai kerumah keluarga pihak laki-laki. Kedua mempelai harus melalui jelanan diwang atau pintu masuk, menuju rumah manten (kamar tidur pengantin), dirumah ini kedua mempelai akan disuguhkan nasi nganten. Kedua calon mempelai tidak diperbolehkan untuk keluar kamar. Keluarga dari calon mempelai laki-laki membuat pejati atau nyalanang pejati ke rumah calon mempelai wanita, balai agung, kelian pauman, kelian dinas dan kepada kepala desa (perbekel) yang mengirimkan mepejati adalah orang yang sudah menikah dan telah memiliki anak. Kedua calon mempelai tidak diperkenankan untuk keluar rumah calon mempelai laki-laki sampai hari baik untuk melangsungkan upacara perkawinan (mebea) tiba.

Dalam sistem adat perkawinan Endogami di desa Tenganan Pengringsingan terdapat banyak simbol-simbol yang dipergunakan dalam pelaksanaan upacara perkawinan tersebut. Berikut ini pembahasan tentang proses pemaknaan simbol-simbol dalam pelaksanaan sistem perkawinan endogami di Desa Tenganan Pengringsingan. Premis pertama teori interaksionisme simbolik karya Blumer dalam Ritzer (2011: 392) adalah manusia bertindak terhadap sesuatu atas dasar makna-makna yang dimiliki benda-benda itu bagi mereka, dalam hal ini masyarakat desa Tenganan Pengringsingan melaksanakan sistem perkawinan Endogami sebagai warisan nenek moyang mereka yang sudah turun-temurun dilaksanakan. Masyarakat Tenganan percaya apabila mereka melanggar tradisi tersebut makan bencana akan melanda desa mereka. Disamping itu, mereka merupakan salah satu dari masyarakat Bali Age (warga asli Bali) akan luntur jika melaksanakan perkawinan dengan orang di luar desa mereka. Sedangkan premis kedua Blumer dalam Ritzer (2011: 392) mengatakan bahwa makna-makna itu merupakan hasil dari interaksi sosial dalam masyarakat manusia satu dengan manusia lainnya. Orang-orang dalam desa Tenganan Pengrisngsingan saling berinteraksi satu dengan lainnya sehingga memaknai simbol-simbol yang ada didalam interaksi tersebut sehingga sampai sekarang. Pada pemuda dan pemudi yang melaksanakan beberapa ritual wajib akan diberikan pengarahan dari pada tetua-tetua adat desa yang berisikan tentang makna-makna yang ada pada setiap kehidupan masyarakat desa Tenganan.

Premis ketiga Blumer dalam Ritzer (2011: 392) Makna-makna dimodifikasikan dan ditangani melalui suatu proses penafsiran yang digunakan oleh setiap individu dalam keterlibatannya dengan tanda-tanda yang dihadapinya yang disempurnakan di saat proses interaksi sosial berlangsung. Masyarakat desa Tenganan menyempurnakan awiq-awiq desa dengan kondisi terkini baik dari lingkungan alam, sosial dan budaya agar mengikuti 
perkembangan jaman tetapi tidak meninggalkan ketentuan yang sudah turun temurun di gariskan pada masyarakat desa. Hadirnya modernisasi pada masyarakat disekitar Desa Tenganan Pengringsingan membawa dampak pada perkembangan desa tersebut. Salah satu yang tetap dilaksanakan adalah sistem perkawinan endogami, terdapat punishment (hukuman) yang akan di dapat oleh anggota masyarakat yang tidak melaksanakan aturan adat tersebut dengan dibuang ke banjar pande / kangin bersama dengan suami di sebelah Timur desa Tenganan Pegringsingan.

Sebelum memberikan makna, penduduk desa Tenganan Pengringsingan terlebih dahulu melakukan serangkaian kegiatan seperti memilik, memeriksa, mengelompokkan, membandingkan, mempredikasi dan mentransformasi makna dalam kaitannya dengan situasi, posisi dana rah tindakannya. Dengan demikian, pemberian maksa tidak hanya didasari pada makna normative (makna yang telah baku sebelumnya) tetapi juga hasil dari proses mental yang secara terus menerus disempurnakan seiring denga perkembangan fungsi instrumentalnya (membentuk dan mengarahkan tindakan serta sikap masyarakat akan sesuatu). Pemaknaan atas sesuatu dilalui dengan proses komunikasi dan interaksi. Interaksi manusia / masyarakat yang akan dijembatani oleh penggunaan simbol-simbol, penapsiran-penapsiran dan kepastian maksa dari tindakan orang lain.

\section{KESIMPULAN}

Dari Pembahasan tersebut dapat disimpulkan bahwa masyarakat Desa Tenganan Pengringsingan mengenal sistem perkawinan endogami desa yaitu perkawinan antar anggota desa, sistem perkawinan ini dipakai karena akan menambah jumlah krama desa suci (karma desa asli). Sistem perkawinan endogami yang dilakukan oleh masyarakat desa Tenganan merupakan sebuah upaya pelestarian nilai-nilai kearifan lokal desa setempat. Selain itu, Sistem perkawinan ini bertujuan agar kepemilikan lahan serta rumah yang ada di desa teta menjadi milik masyarakat desa setempat dan dimiliki oleh masyarakat luar. Dengan melaksanakan pola perkawinan ini secara otomatis pasangan ini akan mendapatkan hak serta melaksanakan kewajiban sesuai dengan awig-awig (aturan) desa yaitu diberikan satu kapling tanah seluas lebih kurang 200 meter persegi serta diperbolehkan menebang pohon-pohon yang ada di hutan untuk membangun rumah. Selain itu, pasangan yang menikah di desa ini juga mendapatan hak atas pemberian beras dari desa yang berasal dari sawah-sawah yang masuk dalam wilayah desa Tenganan serta hak-hak lainnya. Sistem perkawinan endogami yang dilaksanakan di desa ini bukan tanpa hambatan terlebih di jaman modern ini, beberapa anggota masyarakat baik laki- 
laki maupun perempuan melanggar sistem dengan menikahi orang diluar desa, sehingga mereka mendapatkan hukuman karena telah melanggara awig-awig desa. Pelestarian nilai-nilai kearifan lokal yang terjadi di desa Tenganan khususnya sistem perkawinan endogami terbentuk melalui proses komunikasi yang telah terbangun lama. Dalam proses komunikasi tersebut, individu dalam masyarakat melakukan interaksi dan memberikan makna terhadap simbolsimbol yang ada.

\section{DAFTAR PUSTAKA}

Budiana, I Nyoman. 2012. Konstruksi Kawin Nyeburin Antar Wangsa. Denpasar: Undiknas. 2018. Perkawinan Beda Wangsa Dalam Masyarakat Bali. Yogyakarta: Histokultural.

Goode, J William. 2007. Sosiologi Keluarga. Jakarta: Bumi Aksara.

Departemen Pendidikan Indonesia. 2008. Kamus Besar Bahasa Indonesia. Jakarta: Balai Pustaka.

Herusatoto, Budiono. 2012. Mitologi Jawa. Yogyakarta: Oncor Semesta Ilmu.

Irianto, Agus Maladi. 2017. Interaksi simbolik Pendekatan Antropologis Merespon Fenomea Sehari-hari. Semarang:Gigih Pustaka Mandiri.

Sunarto, Kamanto. 2004. Pengantar Sosiologi. Jakarta: Penerbit Fakultas Ekonomi Universitas Indonesia.

Ritzer, George. 2010. Sosiologi Ilmu Pengetahuan Berparadigma Ganda. Jakarta: PT. Raja Grafindo Persada. . 2011. Sosiologi Ilmu Pengetahuan Berparadigma Ganda. Jakarta :Rajawali Pers.

Sugiyono. 2014. Metode Penelitian Pendidikan Pendekatan Kuantitatif, Kualitatif Dan R\&D. Bandung: Alfabeta. 